\title{
16
}

\section{Indigenous peoples and the official statistics system in Aotearoa/New Zealand ${ }^{1}$}

\section{Darin Bishop}

\section{Introduction}

The notion that data do not exist absolutely but are created through measurement highlights the importance of the measurement process in producing relevant knowledge. As Stiglitz et al. (2009: 7) have argued: 'What we measure affects what we do; and if our measurements are flawed, decisions may be distorted.'

This understanding is crucial when considering the implications and concerns raised regarding the collection, ownership and application of statistics pertaining to indigenous peoples. Many national statistics offices (NSOs) around the world have systems in place to derive statistics relating to their indigenous peoples. Arguably, New Zealand has gone further than any other nation-state in seeking to develop

1 The views, opinions, findings and conclusions or recommendations expressed in this chapter are strictly those of the author. They do not necessarily reflect the views of the Ministry of Māori Development (Te Puni Kōkiri) or the New Zealand Government. The Ministry of Māori Development and the New Zealand Government take no responsibility for any errors or omissions in, or for the correctness of, the information contained in this chapter. The chapter is presented not as policy, but with a view to inform and stimulate wider debate. Crown copyright (C) 2015. 
such systems and to accommodate the data needs of its indigenous people. Notwithstanding this, significant deficiencies remain and these undermine Māori data sovereignty.

The focus of this chapter is on the measurement process, its relationship to the production of official statistics on Māori and what this may mean in terms of data sovereignty. The chapter also discusses the challenges and options for collectors and producers of official Māori statistics wanting to improve the information that is readily available.

The main body of the chapter outlines what these deficiencies are and how they undermine data sovereignty. The final section discusses what is required to overcome these deficiencies to meet the data needs of Māori, including the need for Māori to be actively involved in decision-making processes.

\section{Measurement process}

Key stages of the data collection and survey cycle are outlined in Table 16.1. For each stage, decisions are made that collectively form what I refer to as the 'measurement process'. Without an understanding of the various decision-making points, it is difficult to advocate for a more effective system for collecting data on indigenous peoples or to identify future opportunities.

In terms of the collection stage, it is important to understand not only what is collected, why and how, but also what is not collected. At the compilation stage, collectors and producers typically draw on existing statistical rules, guidelines, standards or practices to make decisions. Data users are generally not involved in this part of the process (apart from reviews of standards and classifications). As a result, users do not always understand why compilation decisions are made and what the implications are. For example, what are the data limitations for small populations when confidentiality rules are applied to the data?

At the analysis stage, questions include how indigenous peoples are considered within the analysis, if at all. And, what are the appropriate comparators when assessing indigenous peoples' progress. At the publication stage, the utility of the statistical tools and resulting statistical information for users of statistics regarding indigenous peoples is a key question. 
Table 16.1 Key stages of the data collection and survey cycle

\begin{tabular}{|l|l|}
\hline Stage & Decision-making points \\
\hline Collection & Planning-formulation of objectives \\
& Conceptual measurement \\
& Consultation/engagement \\
& Selection of survey frame and sample design \\
Questionnaire design & Data collection \\
\hline Compilation & $\begin{array}{l}\text { Data capture and coding } \\
\text { Standards and classifications } \\
\text { Application of statistical rules, guidelines or practices } \\
\text { Editing and imputation } \\
\text { Confidentialising of data } \\
\text { Estimation }\end{array}$ \\
\hline Analysis & Comparative analysis \\
\hline Publication & Production and dissemination of official statistics \\
\hline
\end{tabular}

Source: Adapted from Statistics Canada (2003).

In considering these issues, what is obvious is that the resulting information is not produced by chance. Rather, it involves advocacy or lobby groups who influence what is collected; it requires adequate funding and resourcing that also influence what is collected and how appropriate consultation or engagement; and subject matter technical expertise and decision-makers at each stage of the cycle who ultimately determine what data are collected and, equally, what data are not collected and reported.

The measurement process is also vital for empowering indigenous communities and assisting them to identify their own information needs. However, the ability for users of data on indigenous peoples to engage and influence decisions at each stage is both costly and time-consuming. Accordingly, the collectors and producers of official information typically shape the resulting data and information. This is despite increasing efforts by the collectors and producers to better understand the information needs of indigenous peoples, particularly in the context of Aotearoa/New Zealand.

Not surprisingly, in 2004, the United Nations Permanent Forum on Indigenous Issues (UNPFII) convened a workshop on data collection and disaggregation for indigenous peoples (UNPFII 2004). Indigenous representatives questioned the relevance of existing frameworks 
in reflecting their world views and drew attention to their lack of participation in data collection processes and governance (see also Kukutai \& Taylor, this volume).

In addition, the UNPFII workshop identified several recommendations relating to the measurement process and data collection activities for indigenous peoples that are just as relevant today. In particular:

- including questions on indigenous identity in all relevant data collections

- following the principle of free prior and informed consent at all levels

- ensuring data collections are in accordance with human rights provisions, data protection regulations and privacy guarantees, including respect for confidentiality

- participation in all stages of data collection, including planning, implementation, analysis and dissemination, access and return, with appropriate resourcing and capacity-building to do so

- responding to the priorities and aims of the indigenous communities

- where possible, conducting data collection exercises in local indigenous languages

- developing a conceptual framework for rights-based indicators that are relevant to indigenous and tribal peoples

- collecting data specific to the situation of indigenous peoples, while also allowing comparability with other national and international populations.

\section{Realising Māori potential}

From an Aotearoa/New Zealand perspective, Māori statistics are needed for a range of reasons. Māori organisations need statistics to enable them to represent their needs to local and central governments, to perform their community-level functions and to inform their own investment decisions (see Jansen, Hudson, \& Hudson et al., this volume). Here we are concerned more with the perceived needs of governments for data on Māori citizens. Within government, statistics provide the tools and evidence to assist policymakers to develop, target, monitor and report on initiatives with precision and confidence. 
The New Zealand Government has tasked its agencies to deliver better public services for all New Zealanders by setting 10 challenging targets for the public sector to achieve over the next five years (SSC 2015). Furthermore, agencies and entities have developed strategies that directly impact on improving outcomes for Māori within their respective sectors (for example, Ministry of Business, Innovation and Employment 2012, 2014; Ministry of Education 2013; Ministry of Health 2014; Te Taura Whiri i te Reo Māori \& Te Puni Kōkiri 2014). Each strategy has its own Māori outcomes framework and requires relevant data to assess performance and to track progress. Māori statistics are crucial to understanding and reporting the position of Māori within these priorities and strategies.

\section{Te Puni Kōkiri (Ministry of Māori Development)}

Te Puni Kōkiri (the Ministry of Māori Development) was established under the Ministry of Māori Development Act 1991 with responsibility for promoting increased levels of attainment by Māori across a number of specified sectors. In addition to these core policy functions, Te Puni Kōkiri is charged with leading public policy in the Māori development portfolio. The ministry's advisory and program management functions have come to span a wide range of contexts, from social and economic policy as it pertains to Māori through to natural resources, the environment and cultural heritage sectors.

Te Puni Kōkiri has a wide reach despite being a small ministry. It has both a national and a local presence, providing a direct interface with iwi (tribes), hapū (subtribes) and whānau (families including extended families), which is important to meeting their needs as well as facilitating better Crown-Māori relationships and engagement (Te Puni Kōkiri 2015a). Within this context, the ministry needs relevant and reliable evidence to participate fully in formulating, monitoring and assessing policies and programs that contribute to improved results for Māori. The ministry is not a primary collector or producer of official statistics, meaning it relies heavily on other agencies to regularly collect, analyse and produce relevant statistical information for Māori. In this regard, it advocates for the promotion and dissemination of knowledge and encourages informed debate on emerging trends and issues for Māori. 
The government's priorities, targets and strategies discussed above provide a wealth of statistical information on Māori. However, in terms of the measurement process, there is often only a small window of opportunity to influence decisions on the selected indicators and data used to measure progress for Māori within the respective strategies. This also applies when priorities, targets and strategies are reviewed or updated.

It is fair to say that the policy environment shapes the administrative records, surveys and, to some extent, the Census of Population and Dwellings in terms of what data are collected, analysed and reported in the public domain - whether they are about Māori or the population more generally. For example, the return to collecting iwi data in the 1991 Census of Population and Dwellings was primarily instigated by the Māori affairs portfolio, which required this information to monitor the government of the day's proposed policy to devolve delivery of social services to iwi (Statistics New Zealand 1988).

The 'Closing the Gap' and 'Reducing Inequalities' initiatives between the mid-1990s and mid-2000s did not lead to new data-collecting activities, but they did shape the ways in which government agencies and researchers measured and reported on Māori outcomes during that period (see, for example, Chapple \& Rea 1998; Durie 2006). More recently, the government's aim to help whānau become more selfmanaging and take greater responsibility for their own development through the Whānau Ora initiative (Te Puni Kōkiri 2015b) will also influence the future reporting of Māori in the public domain by increasing the need for data that more adequately report on Māori collectives like whānau.

\section{Official statistics on Māori: the Aotearoa/ New Zealand context}

When considering challenges and future options for Māori statistics the starting point is to understand the adequacy of the official statistics system for users or potential users of Māori statistics. There are some fundamental principles to test the system, including whether:

- the data for Māori are readily accessible

- the data for Māori are available in a timely and ongoing manner 
- it is possible to disaggregate the data for Māori by key variables such as age, sex and location (as a minimum requirement)

- the information is meaningful to stakeholders, particularly Māori

- the units of measurement include both Māori individual and Māori collective identities

- the relevant definitions, classifications and methodologies have been developed for Māori

- the system recognises the distinct Māori institutions that exist within Māori society

- the system recognises the social, economic, environmental and cultural areas of Māori development

- appropriate benchmarks and comparators have been developed for Māori within the system.

While the internet and the increased availability of reporting tools have gone some way to address issues in terms of access to information, challenges relating to measurement remain, especially in terms of measuring Māori concepts. These detailed data and information gaps are presented below.

\section{Data and information gaps}

Nearly all of the official statistical information on Māori that is available today was collected as a by-product of social and economic data collected for the total population. As such, it reflects the needs, priorities and concerns of government rather than Māori and, more than that, it reflects the fragmented and incoherent state of social statistics generally.

Despite this, official Māori statistics provide most of the data required for the measurement of socioeconomic outcomes for Māori. Coverage is at its most extensive in the demographic, social and economic areas - a reflection of the nature of the policies that successive past governments pursued in respect of Māori. Prior to the first running of the post-censual Māori social survey, Te Kupenga, ${ }^{2}$ in 2013 (Statistics

2 Te Kupenga is the first national survey specifically designed to capture Māori wellbeing in New Zealand. The survey collected information on a wide range of topics to give an overall picture of the social, cultural and economic wellbeing of Māori. The survey also provides important information about the health of the Māori language and culture. 
New Zealand 2013a), coverage data on Māori cultural difference or indigeneity were limited to a few variables such as Māori descent, ethnic identification, language, knowledge of $i w i$ and some aspects of cultural connectedness.

In reviewing the range of official statistics relating to Māori, it is evident that in some areas national estimates on Māori simply do not existfor example, data on whānau, savings or external migration (see also, Pool, this volume, on the failure of national accounts to accommodate principles of family obligation: whanaungatanga). In other instances, data are collected but the resulting information is reported only for the general population (for example, there is no standard reporting on Māori families or Māori households) or the data are not readily accessible in a way that has utility for Māori (for example, due to the size of the Mãori sample in surveys like the Household Economic Survey). The following provide a summary of outstanding needs in specific areas.

\section{Māori families and households}

Analysis of Māori families and households could provide richer information for policy purposes. While they are a poor substitute for whānau (see Kukutai et al. 2016), they do offer an opportunity to look at individuals in a social context. The regional reports on Tamariki and Rangatahi prepared by Statistics New Zealand in 2001 examine the living arrangements and household circumstances of these two important subpopulations.

Currently, there is no standard output produced by Statistics New Zealand on Māori families or households. This is because, for statistical purposes, ethnicity is an individual characteristic that cannot be applied to a collective such as a family or household (see Davies \& Wereta 2013). Consequently, users define for themselves what a Māori family or household is. Definitions range from ethnicity of the parent(s) and proportion of Māori in the family or household to any member of the family or household identifying as Māori. The use of different definitions means the analyses and trends are not always comparable. 


\section{Māori migration}

While information exists on Māori living in Australia (Kukutai \& Pawar 2013), data to track the movement of Māori leaving and returning to Aotearoa/New Zealand on a regular basis are not readily available. This information is crucial for producing improved estimates and projections of the Māori population and for understanding Māori migration patterns.

\section{Māori business activity}

The need to produce statistics on Māori businesses and Māori business activity was first discussed at the 1984 Hui Taumata (Māori Economic Summit). Despite demand and the developmental work being undertaken in Tatauranga Umanga Māori (Statistics New Zealand 2015a) - a multi-year research project that involves defining, identifying and reporting on Māori authorities and eventually Māori businesses - progress is slow.

\section{Cultural outcomes}

The existing statistics and those proposed by Statistics New Zealand are adequate for the measurement of general social and economic outcomes for Māori, but somewhat limited when it comes to the monitoring of cultural outcomes. Te Kupenga has filled some gaps in relation to cultural connectedness.

\section{Regional data}

Requirements for regional and smaller geographic units complicate the design of samples. Sampling Māori to get the same accuracy level as non-Māori requires Māori to be oversampled. In the past, Statistics New Zealand and the Ministry of Health have used booster samples to get regional data for Māori. Given the limitations, questions must be asked about the capacity of the official statistics system to meet the statistical needs of Māori communities and, indeed, the needs of other small populations.

\section{Cost to produce new data and utilising existing data}

The cost associated with conducting new surveys means it is unlikely that another national-scale Māori survey would run alongside Te Kupenga. This partly reflects the expectation that government 
agencies will continue to make efforts to reduce fiscal costs. It also reflects a drive to investigate alternative ways of using existing administrative records and survey data-for example, Statistics New Zealand's Integrated Data Infrastructure (IDI), a linked longitudinal dataset that covers an extended range of pathways and transitions information.

Making existing information more relevant to Māori will require further thinking, and should include an acceptance from those who lead the official statistics system that nonstandard outputs may be the way of the future within a climate of fiscal constraint.

\section{Timeliness}

Timeliness is also an issue when developing new surveys or measuring new concepts. For example, the idea of a Māori social survey was first mooted in early 2000, but, for a number reasons, the survey was not conducted until 2013.

\section{Unit of measurement}

Official Māori statistics typically use the individual as the basic unit of measurement, meaning that none of the existing data allows the observation of Māori collective entities such as whānau or Māori governance bodies. Accordingly, any resulting analysis is typically about Māori as consumers and producers of goods and services within the wider society, rather than as participants and contributors within Te Ao Māori (the Māori world). This represents a fundamental shortcoming of the official statistical system, not just in Aotearoa/New Zealand but also in other nations with indigenous populations, and the translation of indigenous concepts into existing information systems presents a significant challenge in terms of meeting state obligations under the United Nations Declaration on the Rights of Indigenous Peoples (UNDRIP).

\section{Importance of the Census of Population and Dwellings}

The census is currently the only comprehensive source of population and dwelling statistics for Māori at the tribal and subnational levels. The census provides opportunities to produce knowledge on Māori that is relevant to their information needs across a range of socioeconomic and cultural variables including ethnicity, Māori descent, iwi and language. Inadequacies in other surveys (for example, sample size 
for Māori) and administrative datasets mean that only the census can provide a comprehensive picture of Māori. Due to a combination of constraints, including costs, technical issues and small survey populations, other surveys including Te Kupenga cannot meet the specific needs of community-based Māori organisations.

For electoral purposes, the census is a key information source for determining representation in New Zealand's Parliament, including the number and size of Māori electorates. Furthermore, data are required regarding the protection of Māori culture arising from the Treaty of Waitangi. The census also provides the population frame for Te Kupenga.

Due to the rising costs of running a census, opportunities from new technologies and the increasing availability of alternative data sources, there is discussion about how New Zealand's five-yearly census will be run and how frequently it will be run in the future. These decisions are critical when considering the reliance on the census by data users of Māori statistics, the availability of alternative data sources to produce Māori statistics and the ability to produce Māori population estimates in the future (Statistics New Zealand 2015b).

\section{Building the statistical capability of Māori organisations}

Good information is a critical part of a Māori organisation's infrastructure, planning and decision-making (see Hudson, Hudson et al., \& Jansen, this volume). Given the discussion about the future of the census, there is a clear opportunity to take a lead role in the design or facilitation of a statistical capability program for Māori organisations for which there are two key objectives. The first is to raise awareness and extend the use of existing official statistics by users of Māori statistics, and, second, and perhaps most beneficial, is the ability to transfer skills and capability to Māori organisations to conduct their own community surveys.

\section{The need for an advocacy network}

The number of Māori who use official statistics or have an interest in them is small (but growing) and, as a result, the Māori voice is not always heard within decision-making processes. While the Ministry of Māori Development does have an advocacy role, it is important to be able to influence outcomes both within and outside government. 
An external Māori voice (such as the Te Mana Raraunga, the Māori Data Sovereignty Network) that is independent of the official statistics system can articulate Māori concerns and advocate for Māori interests in language that statisticians can understand (see Kukutai \& Taylor, this volume).

\section{Conclusion}

Just over 20 years ago, Statistics New Zealand started to develop a Māori statistics framework as the basis for building a robust system of statistics for and about Māori. In 2006, that work was presented in the paper 'Towards a Māori statistics framework' (Wereta \& Bishop 2006) at a meeting convened by the UNPFII to discuss indigenous peoples and indicators of wellbeing.

While the content of the framework was not necessarily a surprise to those attending the meeting, what seemed different was that an NSO was attempting to conceptually understand, measure and identify indigenous statistical needs - in this case, Māori statistical needs. Since then, Statistics New Zealand has made considerable gains in continuing to identify and meet the statistical needs of Māori. Some of the gains include:

- a review of the statistics framework and development of $\mathrm{He}$ Arotahi Tatauranga (the Māori Statistics Framework) (Statistics New Zealand 2014)

- statistical information (for example, iwi profiles) becoming more readily accessible through platforms such as the internet (Statistics New Zealand 2015c), with the challenge now being one of relevance in terms of the tools and reports that are produced on Māori, rather than access

- the first running of the Māori social survey, Te Kupenga, in 2013 with production of a series of publications on Māori culture

- a set of tier-one statistics (deemed the most important statistics for understanding how well New Zealand is performing) that includes Māori-specific statistics-namely, financial performance and position of Māori business, whānau connectedness, Māori cultural wellbeing and Māori language use - the significance of which is 
that these statistics have priority status within the official statistics system (Statisphere 2012)

- the use of domain plans for anticipating future statistical needs and priorities for particular areas of interest including Māori environmental statistics (Statistics New Zealand 2013b)

- the (albeit slow) progress of the Tatauranga Umanga Māori project, a multi-year research project that involves defining and identifying Māori authorities, and eventually Māori businesses, and compiling statistics about them (Statistics New Zealand 2015b).

Despite these gains, Kukutai and Walter (2015) raise a number of serious issues that need to be addressed if there are to be continued improvements in the production of official statistics on Māori. These are summarised as a:

recognition of indigenous geographic and cultural diversity; a recognition that current ways of conceptualising the data are not the only, or the most useful, set of practices; a recognition of the need for mutual capability building; and most crucially, recognition of the need for genuine indigenous decision making to shape the functionality of indigenous statistics. (Kukutai \& Walter 2015: 325)

Conceptual measurement of Māori collectives and their activities continues to be a challenge. For example, it is still not clear whether it is possible to measure whānau through the official statistics system. The need for this information is relevant given that whânau outcomes are a central feature of the current government's Māori policy. In the meantime, there is scope to extend the usefulness of available data through analysis of Māori families and households disaggregated on the basis of key social, economic and cultural criteria. Discussions about the transformation and future of the census also raise issues in terms of the availability of official statistics for Māori at the tribal, regional or community level.

There remains the need for an external Māori voice in the official statistics system to articulate and promote the statistical needs of Māori at the national level and engage in the decision-making process (see also Lovett, \& Walter, this volume). However, engagement comes at a price in terms of both dollars and time. 
There is also scope to build the statistical capability of Māori communities and organisations. The benefits would be twofold: raising awareness and use of official statistics by Māori and the transference of skills and capability to Māori organisations to conduct their own community surveys. Also, being more informed has the additional benefit of enabling an external Māori voice and advocacy for Māori statistics. At the same time, the government and its agencies have their own Māori data needs to support their priorities for improving Māori outcomes within their respective sectors.

Finally, indigenous peoples weighing up their participation in the official statistics system and their need for data sovereignty must consider a range of issues. These include their ability to influence the measurement process; the benefit of conducting their own collections and surveys compared with using existing official statistics (including new data initiatives); their subject matter and the technical expertise required to translate indigenous information needs within the system; and their ability, ultimately, to tell indigenous stories using truly indigenous official statistics.

\section{References}

Chapple S \& Rea D (1998). Time series analysis of disparity between Māori and non-Māori labour market outcomes in the Household Labour Force Survey. Labour Market Bulletin 1-2:127-44.

Davies L \& Wereta W (2013). A demographic and statistical profile of whānau from 1975 to the present. In Families Commission (ed.), Families and whannau status report: towards measuring the wellbeing of families and whānau, Families Commission, Wellington.

Durie M (2006). Measuring Māori wellbeing, New Zealand Treasury Guest Lecture Series, Wellington, 1 August 2006.

Kukutai T \& Pawar T (2013). A socio-demographic profile of Māori living in Australia, NIDEA, Hamilton, NZ.

Kukutai T, Sporle A \& Roskruge M (2016). Expressions of whānau. In Families and whānau status report 2016, Social Policy Evaluation and Research Unit, Wellington, www.superu.govt.nz/sites/default/ files/F\%26W\%20Status\%20Report\%202016_2.pdf. 
Kukutai T \& Walter M (2015). Recognition and indigenising official statistics: reflections from Aoteaora New Zealand and Australia. Statistical Journal of the IAOS 31(2):317-26.

Ministry of Business, Innovation and Employment (2012). He kai kei aku ringa: Māori economic strategy and action plan, Ministry of Business, Innovation and Employment/Hīkina Whakatutuki, Wellington.

Ministry of Business, Innovation and Employment (2014). He whare āhuru he oranga tāngata: the Māori housing strategy directions 2014 to 2025, Ministry of Business, Innovation and Employment/Hīkina Whakatutuki, Wellington.

Ministry of Education (2013). The Māori education strategy: ka hikitiaaccelerating success 2013-2017, Ministry of Education, Wellington.

Ministry of Health (2014). He korowai oranga: Māori health strategy, 2014, Ministry of Health, Wellington.

State Services Commission (SSC) (2015). Better public services, State Services Commission, Wellington, ssc.govt.nz/better-publicservices.

Statisphere (2012). Tier 1 statistics, Statistics New Zealand, Wellington, statisphere.govt.nz/tierl-statistics.aspx.

Statistics Canada (2003). Survey methods and practices, Catalogue No. 12-587-X, Statistics Canada, Ottawa.

Statistics New Zealand (1988). Report of the review committee on ethnic statistics, Department of Statistics, Wellington.

Statistics New Zealand (2001). Tamariki and Rangatahi Māori regional reports, Statistics New Zealand, Wellington.

Statistics New Zealand (2013a). Te kupenga, Statistics New Zealand, Wellington, stats.govt.nz/browse_for_stats/people_and_communities /maori/te-kupenga.aspx.

Statistics New Zealand (2013b). Māori environmental statistics, Statistics New Zealand, Wellington, stats.govt.nz/browse_for_stats/ environment/environmental-economic-accounts/environmentdomain-plan/maori-environmental-stats.aspx. 
Statistics New Zealand (2014). He arotahi tatauranga, Statistics New Zealand, Wellington, stats.govt.nz/browse_for_stats/people_and_ communities/maori/how-to-think-maori-info-needs/he-arotahitatauranga.aspx.

Statistics New Zealand (2015a). Tatauranga umanga Māori, Statistics New Zealand, Wellington, stats.govt.nz/browse_for_stats/people_ and_communities/maori/tatauranga-umanga-maori-2015.aspx\#.

Statistics New Zealand (2015b). Census transformation: a promising future, Statistics New Zealand, Wellington, stats.govt.nz/about_ us/what-we-do/our-publications/cabinet-papers/census-transpromising-future.aspx.

Statistics New Zealand (2015c). Iwi profiles, Statistics New Zealand, Wellington, stats.govt.nz/searchresults.aspx?q=iwi\%20profiles.

Stiglitz J, Sen A \& Fitoussi J (2009). Report by the Commission on the Measurement of Economic Performance and Social Progress, Paris, www.insee.fr/fr/publications-et-services/dossiers_web/stiglitz/ doc-commission/RAPPORT_anglais.pdf.

Te Puni Kōkiri (2015a). He uru whetū, he ara haere: strategic intentions 2015-19, Te Puni Kōkiri, Wellington.

Te Puni Kōkiri (2015b). Whānau ora, Te Puni Kōkiri, Wellington, tpk.govt.nz/en/whakamahia/whanau-ora/.

Te Taura Whiri i te Reo Māori \& Te Puni Kōkiri (2014). Te rautaki reo Māori: Māori language strategy 2014, Te Puni Kōkiri, Wellington.

United Nations Permanent Forum on Indigenous Issues (UNPFII) (2004). Report of the workshop on data collection and disaggregation for indigenous peoples, E/c.19/2004/1, United Nations, New York, 1-21 May 2004.

Wereta W \& Bishop D (2006). Towards a Māori statistics framework. In White JP, Wingert S, Beavon D \& Maxim P (eds), Aboriginal policy research: moving forward, making a difference, Thompson Educational Publishing, Toronto. 
This text is taken from Indigenous Data Sovereignty: Toward an agenda, edited by Tahu Kukutai and John Taylor, published 2016 by ANU Press, The Australian National University, Canberra, Australia. 